\title{
Izabela Morawska
}

(iD) https://orcid.org/0000-0002-5404-9104

Department of Accounting

Faculty of Finance

University of Economics, Katowice, Poland

izabela.morawska@uekat.pl

\section{The impact of the IFRS 15 implementation on the revenue-based earnings management in Poland}

Accepted by Editor Ewa Ziemba | Received: June 21, 2021 | Revised: October 19, 2021; November 9, 2021 | Accepted: November 9, 2021 | Published: December 2, 2021.

(C) 2021 Author(s). This article is licensed under the Creative Commons Attribution-NonCommercial 4.0 license (https://creativecommons.org/licenses/by-nc/4.0/)

\section{Abstract}

Aim/purpose - This paper aims at investigating whether the International Financial Reporting Standard (IFRS) 15 Revenue from Contracts with Customers implementation in Poland has affected earnings management that uses discretion in revenue recognition to avoid losses and earnings decreases.

Design/methodology/approach - The empirical studies were conducted using a sample of 80 entities from four industries listed on the Warsaw Stock Exchange (WSE) in Poland from 2016 to 2019. Caylor's (2010) revenue-based model was applied, and an econometric model describing the studied relation was built and verified to this end.

Findings - The analyzed entities managed earnings using discretion in accrued revenue recognition to avoid reporting losses. The research results did not confirm that the IFRS 15 adoption in Poland influenced revenue-based earnings management aimed at avoiding losses and earnings decreases.

Research implications/limitations - This study warns of the role played by discretion in revenue recognition and recommends careful recognition of revenue under IFRS 15. Limitations of this study are generally related to the models' specification and a relatively small number of the entities studied.

Originality/value/contribution - This study contributes to the literature on revenue-based earnings management and is one of the first studies on the association between IFRS 15 adoption and revenue-based earnings management in Poland. Thus, this study bridges the research gap in Poland.

Cite as: Morawska, I. (2021). The impact of the IFRS 15 implementation on the revenue-based earnings management in Poland. Journal of Economics \& Management, 43, 387-403. https://doi.org/10.22367/ jem.2021.43.18 
Keywords: IFRS 15, earnings management, revenue recognition, earnings benchmarks. JEL Classification: M40, M41, M48.

\section{Introduction}

One of the most crucial changes in International Accounting Standards (IAS) and International Financial Reporting Standards (IFRS) is the introduction of the new revenue recognition standard IFRS 15 Revenue from Contracts with Customers (Poniatowska, 2019). In Poland, this standard entered into force on January 1, 2018, and replaced the previously applicable international revenue standards, i.e., IAS 18 Revenue, IAS 11 Construction Contracts, and related interpretations.

The consequences of the IFRS 15 adoption could have two possible directions (Piosik, 2021; Rutledge, Karim, \& Kim; 2016, Sitarz, 2018). On the one hand, there can be an increase in the comparability of accounting information about revenue between companies from various sectors and countries (Walińska \& Jurewicz, 2015), the appropriateness of the assessment of the company's business model (Karwowski, 2016), and the quality of the information included in the financial reports (Altaji \& Alokdeh, 2019). On the other hand, applying the new revenue recognition procedure requires making more estimations and using more professional judgments (Holder et al., 2014; Poniatowska, 2019). As stated by Staszel (2019) and Wójtowicz (2010), it would increase the possibilities of earnings management practices and manipulating reporting data.

In connection with the above, a research question arises whether the managers of Polish companies preparing financial statements under IAS/IFRS wanted and used the potential increase in the ability of the revenue-based earnings management caused by the IFRS 15 implementation. This paper aims at answering this question, but due to the multiplicity of the earnings management's instruments and goals, the research area was narrowed down to the earnings management aimed at avoiding losses and earnings decreases - the most frequent incentives for earnings management (Brzeszczyński, Gajdka, \& Schabek, 2011; Burgstahler \& Dichev, 1997; Dechow \& Skinner, 2000).

Therefore, this paper aims at investigating whether the IFRS 15 implementation in Poland has affected earnings management that uses discretion in revenue recognition to avoid losses and earnings decreases. To realize this goal, the empirical studies were conducted using a sample of 80 companies from four industries listed on the Warsaw Stock Exchange (WSE) from 2016 to 2019. 
Caylor's (2010) revenue-based model was applied to this end, from which residuals were estimated using cross-sectional multiple regression. Then the model that describes the relationship between magnitudes of discretionary revenue (the residuals of Caylor's (2010) model) and variables that relate to the IFRS 15 introduction and the proxies of earnings management aimed at avoiding losses and earnings decreases was verified using pooled Ordinary Least Square (OLS) regression model.

The motivation of this study is that many authors have proven that revenue recognition is one of the most popular and relevant instruments of earnings management (Boterenbrood, 2014; Graham et al, 2005; Marquardt \& Wiedman, 2004; Plummer \& Mest, 2001), and there is a narrow scope of empirical research on the relationship between the IFRS 15 adoption and earnings management practices. To date, the empirical research on the impact of IFRS 15 implementation on earnings management has generally been conducted only by Tutino, Regoliosi, Mattei, Paoloni, and Pompili (2018) and Piosik (2021). The authors of the former research studied Italian listed entities and proved that the earnings management practices were more pronounced in the telecommunications sector than in the utility sector, and that is why the IFRS 15 introduction would have a higher impact on the magnitude of earnings management in the companies from the telecommunications sector than in those from the utility sector. Piosik (2021) found that IFRS 15 implementation in Poland significantly mitigated the discretionary increase in revenue when studied companies failed to meet analysts' consensus forecasts for operating profit. However, he did not observe any effect of IFRS 15 adoption on mitigating the discretionary revenue increase when studied companies failed to meet the consensus on net earnings.

The remainder of this paper is organized as follows. The first section introduces the research topic. The second part of the paper gives a review of the literature. The third section describes the methodology of the present empirical study and procedures. The fourth, empirical section presents the findings of this study. This is followed by the section with the discussion and the conclusions, where the research contribution as well the implications for science and practice are highlighted, and the directions for future studies are suggested. Finally, the paper ends with the acknowledgments. 


\section{Literature review and hypothesis development}

\subsection{Prior research on earnings management's incentives and instruments}

The problem of earnings management has been reoccurring in the financial reporting process for many years (Strojek-Filus, 2016) and permanently remains an area of interest in plenty of research on financial-decision-taking mechanisms (Piasecki, 2015). A large number of empirical studies showed that entities' managers manage earnings guided by certain motives (Healy \& Wahlen, 1999; Malofeeva, 2018). Many authors (Kałdoński \& Jewartowski, 2018; Lizińska \& Czapiewski, 2016; Piosik \& Genge, 2020) hypothesized that one of the most frequent incentives for earnings management is meeting/beating earnings benchmarks, which often leads to avoidance of accounting loss and earnings reduction. The occurrence of this intention was confirmed by Dechow and Skinner (2000), Burgstahler and Dichev (1997), Beatty, Ke, and Petroni (2002), Hamdi and Zarai (2012), and Glaum, Lichtblau, and Lindemann (2004). Furthermore, the results of the research conducted by Brzeszczyński et al. (2011) indicated that managers of entities listed on the WSE in Poland also had such a goal of earnings management.

Earnings management goals, such as the above-mentioned avoidance of reporting losses and earnings decreases, can be achieved through several techniques (Toumeh \& Yahya, 2019) but many studies evidenced that one of the key instruments used to manage earnings is revenue recognition (Marquardt \& Wiedman, 2004; Serdarević \& Muratović-Dedić, 2021; Stallworth \& Digregorio, 2004; Stallworth \& Braun, 2007).

The revenue-based earnings management relies on using discretion in revenue recognition and can be conducted through the use of discretion in both deferred revenue (i.e., advances from customers) and accrued revenue (i.e., trade accounts receivable) (Caylor, 2010).This is why the following two-fold hypothesis is proposed:

H1.1: Entities manage earnings using discretion in accrued revenue recognition to avoid losses and earnings decreases.

H1.2: Entities manage earnings using discretion in deferred revenue recognition to avoid losses and earnings decreases. 


\subsection{Prior research on earnings management and rules of revenue recognition}

In research on revenue-based earnings management, the analyses of the association between the implementation of revenue recognition regulations and related managers' practices play an essential role (Piosik, 2021). This is because the rules contained in those regulations and their changes significantly impact on the magnitude of using discretion in revenue recognition. Kasznik (2001) evidenced that managers used discretion and accelerated revenue recognition in the period prior to the Statement of Position (SOP) 91-1 implementation to convey private information about their entities' underlying economics. Consistent results were also gained by Zhang's (2005), however, he also suggested that the cost of higher information relevance is the reduction of its reliability. Altamuro, Beatty, \& Weber (2005) found that a sub-sample of entities affected by the Security and Exchange Commission's (SEC) Staff Accounting Bulletin (SAB) No. 101 accelerated revenue recognition to avoid income reduction and reporting losses. Research conducted by Baldissera et al. (2018) on construction companies listed on the Brasil Bolsa Balcão indicated that there was a significant difference in earnings management practices before and after Technical Pronouncement CPC 17 Construction Contracts adoption, and that the standard had a negative influence on the earnings management level in those entities. Caylor (2010) studied whether companies managed earnings using discretion in accrued and deferred revenue recognition to avoid reporting losses and income reduction and considered the impact of the Sarbanes-Oxley Act (SOX) implementation on such practices. He found that managers used discretion in revenue recognition to avoid negative earnings surprises. He also proved that managers used discretion in the deferred revenue recognition more often than in the accrued revenue recognition in the pre-SOX period.

Caylor's (2010) study adopted an interesting research methodology - he used abnormal revenue estimates as proxies of earnings management and these seem to be more appropriate in detecting revenue-based earnings management practices than "classic" methods involving total accruals models. This approach to detecting earnings management practices using revenue recognition was also used by Stubben (2010) and Giedt (2018). Stubben (2010) examined the ability of accrual and revenue models to detect earnings management practices. He modeled premature revenue recognition and its effect on the relationship between revenue and accounts receivable. The results of the comparative analysis 
of accrual and revenue models indicated that revenue models were better specified, less biased, and more powerful than accrual models. Giedt (2018) came to similar conclusions. She provided a comprehensive three-part model for detecting revenue-based earnings management and found some empirical evidence that modeling more specific accruals (just like revenue), rather than total accruals, would result in more adequate identification of earnings management. These findings contribute to the construction of this paper's research methodology.

As mentioned in the Introduction, the relationship between the magnitude of revenue-based earnings management and the IFRS 15 introduction was studied only in two publications. Tutino et al. (2019) found that the IFRS 15 implementation had a higher impact on earnings management magnitude in Italian listed companies from the telecommunication sector than in the utility sector. Piosik (2021) used a sample of entities listed on the WSE and shed light on the fact that IFRS 15 implementation in Poland significantly mitigated the discretionary revenue increase when entities failed to meet analysts' consensus forecasts for operating profit. However, he did not confirm that such a phenomenon occurred for entities that failed to meet the consensus on net earnings.

It should be noted that the purpose of the IFRS/IAS setting and applying is to make the information in financial reports high quality, transparent, and comparable (Toumeh \& Yahya, 2019). Therefore, it could be expected that the IFRS 15 adoption will positively affect the quality of financial reports. Altaji and Alokdeh (2019) found that the IFRS 15 introduction in Jordan had a statistically significant impact on improving the relevance and faithful presentation of accounting information.

In the connection with the above, the second two-fold hypothesis is as follows:

H2.1: The IFRS 15 adoption reduces the magnitude of earnings management practices aimed at avoiding losses and earnings decreases, which use discretion in accrued revenue recognition.

H2.2: The IFRS 15 adoption reduces the magnitude of earnings management practices aimed at avoiding losses and earnings decreases, which use discretion in deferred revenue recognition. 


\section{Data and research methodology}

\subsection{Research sample}

The research sample included entities listed on the Warsaw Stock Exchange that belong to the construction, IT and new technologies, energy, and electromechanical industries, for which all the following conditions are met simultaneously:

- shares of these entities were traded on the WSE continuously from 2016 to 2019 ,

- the financial statements of these entities were prepared under IFRS and were publicly available, and

- those financial statements contained all data required to conduct the research.

After eliminating entities not meeting the above-described conditions, the research sample consisted of 80 entities, including:

- 11 entities from the energy industry,

- 23 entities from the electromechanical industry,

- 29 entities from the construction industry, and

-17 entities from the IT and new technologies industry.

\subsection{Identification of abnormal changes in gross accounts receivable and abnormal changes in short-term deferred revenue}

The measurement of earnings management practices using discretion in accrued revenue causes abnormal changes in gross accounts receivable. These changes are the residuals of Caylor's (2010) model of normal changes in gross accounts receivable. This model has the following form:

$$
\frac{\Delta G \operatorname{GossAR} i t}{T A_{i(t-1)}}=\alpha_{0}+\alpha_{1}\left(\frac{1}{T A_{i(t-1)}}\right)+\alpha_{2}\left(\frac{\Delta R E V_{i t}}{T A_{i(t-1)}}\right)+\alpha_{3}\left(\frac{\Delta C F O_{i(t+1)}}{T A_{i(t-1)}}\right)+\varepsilon_{i t}
$$

where:

$\triangle$ Gross $A R_{i t}-$ change in gross accounts receivable, $T A_{i t}$ - total assets, $\triangle R E V_{i t}$ - change in sales revenue, $\triangle C F O_{i t}-$ change in cash flow from operations, $\varepsilon_{i t}$ - residuals of the model (further in the text: $R\left(\operatorname{Gross}_{A} R_{i t}\right)$ ),

$i$ - company, $i=1,2, \ldots, n$,

$t$ - time period, $t=1,2, \ldots, T$. 
The more negative the $R\left(G r o s s A R_{i t}\right)$ value is, the greater level of earnings management is.

To meet/beat earnings targets, managers can also manage their company's earnings through using discretion in short-term deferred revenue recognition. This could be measured as abnormal changes in short-term deferred revenue. To estimate this amount, the following Caylor's (2010) model has been used:

$$
\frac{\Delta \text { DefREV }_{i t}}{T A_{i(t-1)}}=\alpha_{0}+\alpha_{1}\left(\frac{1}{T A_{i(t-1)}}\right)+\alpha_{2}\left(\frac{\Delta R E V_{i(t+1)}}{T A_{i(t-1)}}\right)+\alpha_{3}\left(\frac{\Delta C F O_{i t}}{T A_{i(t-1)}}\right)+\varepsilon_{i t}
$$

where:

$\triangle D e f R E V_{i t}$ - change in short-term deferred revenue, $\varepsilon_{i t}$ - residuals of the model (further in the text: $R\left(\right.$ GrossDefREV $\left._{i t}\right)$ ).

Other symbols of variables are the same as in Equation (1)

Higher abnormal changes in short-term deferred revenue (higher $R($ GrossDefREVit)) indicate a greater level of earnings management.

Both models described above are cross-sectional multiple regressions, executed separately for every year and industry. To estimate these regressions, the Statistica Software 13.3 was used.

\subsection{Modeling the relationship between the IFRS 15 implementation and earnings management using discretion in revenue recognition}

To investigate the association between the IFRS 15 implementation and the proxies of earnings management which uses discretion in revenue recognition, the following empirical model was built and verified:

$$
\begin{gathered}
R V_{i t}=\beta_{0}+\beta_{1} I F R S 15_{i t}+\beta_{2} \text { preMNG_JM } M_{i t}+\beta_{3} \text { preMNG_MJB } B_{i t}+ \\
+\beta_{4} I F R S 15_{i t} \text { preMNG_JM } M_{i t}+\beta_{5} I F R S 15_{i t} \text { preMNG_MJB } i t+\beta_{6} R O A_{i t}+ \\
+\beta_{7} S I Z E_{i t}+\beta_{8} L E V_{i t}+\delta_{i t}
\end{gathered}
$$

where:

$R V_{i t}$ - one of the residuals of Caylor's (2010) model, i.e., abnormal changes in accounts receivable $\left(G_{\left.\text {ross } A R_{i t}\right)}\right.$ ) or abnormal changes in short-term deferred revenue $\left(\right.$ DefREV $\left._{i t}\right)$,

IFRS15 1 - a binary variable equal to 1 if IFRS 15 was implemented, and 0 otherwise, 
preMNG_JM $M_{i t}$ - a binary variable equal to 1 if a net income adjusted by the residuals from the Caylor's (2010) model and scaled by lagged total assets is higher than -0.02 and lower than 0 , and 0 otherwise, preMNG_MJB $B_{i t}$ - a binary variable equal to 1 if the change in net income adjusted by the residuals from the Caylor's (2010) model and scaled by lagged total assets is higher than 0 and lower than 0.02 , and 0 otherwise, $R O A_{i t}$ - return on assets, equal to reported net income divided by total assets, $S I Z E_{i t}$ - an entity's size measured as the natural logarithm of total assets, $L E V_{i t}$ - the financial leverage, which is lagged total liabilities divided by lagged total assets, $\delta_{i t}$ - residuals of the model.

The variables in the presented model are in accordance with the hypotheses described in the previous section. The parameters of this model, for both $R\left(G r o s s A R_{i t}\right)$ and $R\left(D e f R E V_{i t}\right)$, were estimated in Gretl software using panel regression. Piosik's (2021) method of panel regression analysis was followed to select an appropriate panel model, and panel diagnostic tests were carried out. Table 1 presents the results of these tests.

Table 1. Results of the panel diagnostic tests

\begin{tabular}{|l|l|l|}
\hline \multicolumn{1}{|c|}{ The model } & $\begin{array}{c}\text { The model with dependent variable } \\
R(\text { GrossAR })\end{array}$ & \multicolumn{1}{|c|}{$\begin{array}{c}\text { The model with dependent } \\
\text { variable } R(\text { DefREV })\end{array}$} \\
\hline Hausman test & $\mathrm{df}=8 ; \chi^{2}=5.911 ; \mathrm{p}=0.657$ & $\mathrm{df}=8 ; \chi^{2}=7.384 ; \mathrm{p}=0.496$ \\
\hline $\begin{array}{l}\text { Test F for individual } \\
\text { effects }\end{array}$ & $\begin{array}{l}\mathrm{df} 1=79 ; \mathrm{df} 2=152 ; \mathrm{F}=0.898 ; \\
\mathrm{p}=0.701\end{array}$ & $\begin{array}{l}\mathrm{df} 1=79 ; \mathrm{df} 2=152 ; \mathrm{F}=0.896 ; \\
\mathrm{p}=0.704\end{array}$ \\
\hline $\begin{array}{l}\text { Breusch-Pagan Lagrange } \\
\text { Multiplier Test }\end{array}$ & $\mathrm{df}=1 ; \chi^{2}=0.278 ; \mathrm{p}=0.598$ & $\mathrm{df}=1 ; \chi^{2}=0.302 ; \mathrm{p}=0.583$ \\
\hline $\begin{array}{l}\text { Wald test for time } \\
\text { effects }\end{array}$ & $\mathrm{df}=2 ; \chi^{2}=0.140 ; \mathrm{p}=0.932$ & $\mathrm{df}=2 ; \chi^{2}=2.694 ; \mathrm{p}=0.260$ \\
\hline
\end{tabular}

Source: Author's own results of operations in Gretl Software.

The analysis of the panel diagnostic results presented in Table 1 indicated that for both $R(G r o s s A R)$ and $R(D e f R E V)$ models, the pooled OLS regression model was better suited to the data than the fixed and random effects regression model. The Wald tests results showed that there were on time effects. Thus, there was no need for including dummy explanatory variables for the years in regression. 


\section{Results}

\subsection{Descriptive statistics and correlations}

Table 2 and Table 3 include the descriptive statistics for the variables used in Equation (3).

Table 2. Descriptive statistics for the variables from the model with dependent variable $R($ GrossAR)

\begin{tabular}{|c|c|c|c|c|c|}
\hline Variable & Mean & Std. Dev. & $\begin{array}{c}25 \% \\
\text { Quartile }\end{array}$ & Median & $\begin{array}{c}75 \% \\
\text { Quartile }\end{array}$ \\
\hline$R($ GrossAR $)$ & 0.000 & 0.063 & -0.027 & -0.004 & 0.031 \\
\hline IFRS15 & 0.333 & 0.472 & 0.000 & 0.000 & 1.000 \\
\hline preMNG_JM & 0.000 & 0.180 & 0.000 & 0.000 & 0.000 \\
\hline preMNG_MJB & 0.196 & 0.398 & 0.000 & 0.000 & 0.000 \\
\hline IFRS $15 \times$ x preMNG_JM & 0.008 & 0.091 & 0.000 & 0.000 & 0.000 \\
\hline IFRSI5 x preMNG_MJB & 0.067 & 0.250 & 0.000 & 0.000 & 0.000 \\
\hline$R O A$ & 0.008 & 0.170 & 0.004 & 0.033 & 0.066 \\
\hline SIZE & 12.873 & 1.886 & 11.827 & 12.785 & 13.737 \\
\hline$L E V$ & 0.479 & 0.212 & 0.352 & 0.470 & 0.579 \\
\hline
\end{tabular}

Source: Author's own calculations in Statistica Software.

Mean and median values reported in Table 2 can indicate that:

- the studied group of entities had not missed the earnings benchmark formed as nonnegative earnings, i.e., had been avoiding reporting losses using discretion in accrued revenue recognition,

- on average, less than $20 \%$ of studied entities had beaten the earnings benchmark formed as the previous year's financial result, i.e., had been avoiding earnings decreases using discretion in accrued revenue recognition.

Table 3. Descriptive statistics for the variables from the model with dependent variable $R(D e f R E V)$

\begin{tabular}{|l|r|r|r|r|r|}
\hline \multicolumn{1}{|c|}{ Variable } & \multicolumn{1}{c|}{ Mean } & \multicolumn{1}{c|}{ Std. Dev. } & \multicolumn{1}{c|}{$\begin{array}{c}\text { 25\% } \\
\text { Quartile }\end{array}$} & \multicolumn{1}{c|}{ Median } & \multicolumn{1}{c|}{$\begin{array}{c}75 \% \\
\text { Quartile }\end{array}$} \\
\hline$R($ DefREV $)$ & 0.000 & 0.030 & -0.011 & 0.001 & 0.010 \\
\hline IFRS15 & 0.333 & 0.472 & 0.000 & 0.000 & 1.000 \\
\hline preMNG_JM & 0.033 & 0.180 & 0.000 & 0.000 & 0.000 \\
\hline preMNG_MJB & 0.150 & 0.358 & 0.000 & 0.000 & 0.000 \\
\hline IFRS15 x preMNG_JM & 0.008 & 0.091 & 0.000 & 0.000 & 0.000 \\
\hline IFRS15 x preMNG_MJB & 0.050 & 0.218 & 0.000 & 0.000 & 0.000 \\
\hline ROA & 0.008 & 0.170 & 0.004 & 0.033 & 0.066 \\
\hline SIZE & 12.873 & 1.886 & 11.827 & 12.785 & 13.737 \\
\hline LEV & 0.479 & 0.212 & 0.352 & 0.470 & 0.579 \\
\hline
\end{tabular}

Source: Author's own calculations in Statistica Software. 
Mean proxies included in Table 3 can signal that:

- on average, approximately $3 \%$ of analyzed entities had missed the earnings benchmark formed as nonnegative earnings; thus, the rest of the studied companies could have been avoiding reporting losses using discretion in deferred revenue recognition,

- on average, $15 \%$ of studied companies had been avoiding reporting lower financial result than in the previous year.

Table 4 presents the correlation matrix of Spearman's correlation coefficients between pairs of continuous variables used in the Equation (3). Significant coefficients are in boldface (at $\mathrm{p}=0.1$ ).

Table 4. Matrix with Spearman's correlation coefficients

\begin{tabular}{|c|c|c|c|c|c|}
\hline Variable & $R($ Gross $A R)$ & $R(D e f R E V)$ & $R O A$ & SIZE & $L E V$ \\
\hline$R($ GrossAR $)$ & 1.000 & 0.080 & 0.047 & -0.023 & -0.078 \\
\hline$R(D e f R E V)$ & & 1.000 & -0.064 & -0.017 & -0.009 \\
\hline$R O A$ & & & 1.000 & -0.117 & -0.294 \\
\hline SIZE & & & & 1.000 & 0.344 \\
\hline$L E V$ & & & & & 1.000 \\
\hline
\end{tabular}

Source: Author's own calculations in Statistica Software.

\subsection{Pooled OLS regression results}

Table 5 shows the pooled OLS regression results for the dependent variables $R(\operatorname{Gross} A R)$ and $R(\operatorname{DefREV})$ from the model (3). Again, significant coefficients are in boldface (at $\mathrm{p}=0.1$ ).

The results presented in Table 5 show that there is a negative ${ }^{1}$ and statistically significant relationship between $R($ Gross $A R)$ and the explanatory variable preMNG_JM, which means that managers of studied entities generally were avoiding reporting losses using discretion in accrued revenue recognition. However, there is no evidence that they did so with the use of discretion in deferred revenue recognition. The results of the above regression estimations also indicated that there was no link between the dependent variables $R(\operatorname{Gross} A R)$ and $R(\operatorname{DefRev})$ and the explanatory variable preMNG_MJB, and this could mean that, even if the studied group of companies avoided decreases in earnings to some extent, they had not done so using revenue-based earnings management.

\footnotetext{
${ }^{1}$ Residuals from the model of abnormal changes in accounts receivable are negative, and it results in opposite way of interpretation of the sign of the correlation.
} 
Table 5. Pooled OLS regression results for $R(G r o s s A R)$ and $R(D e f R E V)$

\begin{tabular}{|c|c|c|c|c|c|c|}
\hline Dependent variable & \multicolumn{3}{|c|}{$R($ Gross $A R)$} & \multicolumn{3}{|c|}{$R(D e f R E V)$} \\
\hline Explanatory variables: & Coeff. & St. Error & $\mathrm{p}$ & Coeff. & St. Error & $\mathrm{p}$ \\
\hline Constant & 0.005 & 0.028 & 0.858 & 0.004 & 0.013 & 0.757 \\
\hline IFRS15 & 0.002 & 0.009 & 0.820 & 0.003 & 0.005 & 0.500 \\
\hline preMNG_JM & 0.066 & 0.026 & 0.012 & 0.005 & 0.012 & 0.687 \\
\hline preMNG_MJB & 0.012 & 0.013 & 0.327 & 0.009 & 0.007 & 0.184 \\
\hline IFRS15 $\mathrm{x}$ preMNG_JM & -0.057 & 0.052 & 0.270 & -0.003 & 0.025 & 0.887 \\
\hline IFRS15 $\mathrm{x}$ preMNG_MJB & -0.004 & 0.022 & 0.861 & -0.010 & 0.011 & 0.394 \\
\hline$R O A$ & 0.056 & 0.025 & 0.024 & -0.025 & 0.012 & 0.031 \\
\hline SIZE & -0.000 & 0.002 & 0.898 & 0.000 & 0.001 & 0.721 \\
\hline$L E V$ & -0.013 & 0.020 & 0.504 & -0.023 & 0.010 & 0.020 \\
\hline \multicolumn{7}{|l|}{ Model characteristics: } \\
\hline $\mathrm{R}^{2}$ & & & 0.058 & & & 0.039 \\
\hline Adj. $R^{2}$ & & & 0.026 & & & 0.005 \\
\hline $\mathrm{F}(8.231)$ & & & 1.799 & & & 1.162 \\
\hline $\mathrm{p}$ & & & 0.07 & & & 0.323 \\
\hline
\end{tabular}

Source: Author's own operations in Gretl Software.

The pooled OLS regression analysis did not provide any confirmation that the implementation of IFRS 15 affected revenue-based earnings management because there was no statistically significant link between the dependent variables $R($ Gross $A R)$ and $R(D e f R E V)$, and any explanatory variable connected with the IFRS 15 application.

\section{Discussion, conclusions and limitations}

The findings of the above-presented statistical analysis brought to light that managers of the studied group of entities managed earnings with the use of discretion in accrued revenue recognition to avoid reporting losses, and that the relationship was statistically significant. Therefore, Hypothesis H1.1 was confirmed. These results to some extend are consistent with the findings of Roychowdhury (2006), who proved that managers managed earnings with the use of revenue-based real activities such as price discounts to temporarily avoid reporting losses.

Due to the lack of a statistically significant relationship between earnings management using discretion in accrued revenue recognition and the avoidance of reporting earnings decreases, there was no possibility of confirming Hypothesis H1.2. 
Statistical analysis conducted in this paper did not allow to clearly specify the impact of the IFRS 15 adoption on the magnitude of earnings management practices using discretion in revenue recognition. The pooled OLS regression results did not confirm if there was any relationship between the IFRS 15 adoption and the abnormal changes in short-term deferred revenue. The regression analysis did also not affirm that the IFRS 15 implementation could significantly influence earnings management practices using discretion in accrued revenue recognition. The pooled OLS regression results indicated that there was no significant link between the IFRS 15 adoption and revenue-based earnings management aimed at meeting/beating targets. That is why Hypotheses H2.1 and H2.2 were not confirmed. This lack of the clear specification of the relationship between the IFRS 15 adoption and the magnitude of revenue-based earnings management can be associated with the bidirectional impact of IFRS 15 on the quality of earnings and the possibilities of earnings management, which was emphasized by Rutledge et al. (2018) and Sitarz (2018).

The results of the analyses conducted in this study confirmed that companies managed earnings to achieve earnings benchmarks, and this is consistent with findings provided by Brzeszczyński et al. (2011), Piosik and Genge (2020), Dechow and Skinner (2000), Burgstahler and Dichev (1997), Beatty et al. (2002), Hamdi and Zarai (2012), and Glaum et al. (2004).

An important research issue in this study is the confirmation that companies managed earnings using discretion in revenue recognition, and it contributes to the literature, which has proven that discretionary revenue recognition is one of the key instruments of earnings management (Boterenbrood, 2014; Marquardt \& Wiedman, 2004; Plummer \& Mest, 2001).

This study has implications for science and practice. First of all, this study contributes to international research on revenue-based earnings management because the obtained results showed that managers of Polish companies also use discretion in revenue recognition to manage earnings. It is also worth noting that this paper is one of the first studies on revenue-based earnings management in Poland and the impact of the IFRS 15 adoption on such managers' practices in Poland. Even if it was not confirmed that the IFRS 15 application in Poland influenced revenue-based earnings management practices, this study contributes to filling the research gap on this topic. From the business practice point of view, the results of this study recommend that auditors, investors, and other users of financial reports should be aware of the role played by discretion in revenue recognition, and they should carefully read the disclosures about revenue con- 
tained in financial reports. Moreover, there is a recommendation for preparers of financial reports to apply the revenue recognition rules contained in IFRS 15 with care and attention.

The study faced particular limitations that should be taken into account while interpreting the obtained results. First, the number of the studied entities is relatively small. Second, the specification of Caylor's model (2010) resulted in deficient use of the data from 2019 - the collected financial information from this year was only used in the variable with " $t+1$ " connotation and could not be included in the statistical analyses.

The consequence of this study's results and limitations is a need for further studies on the impact of the IFRS 15 adoption on earnings management, in which a larger group of entities should be used, other incentives for earnings management could be examined, and use of alternative revenue model to detect earnings management could be considered.

\section{Acknowledgements}

I wish to express appreciation to Professor Andrzej Piosik for his expert help and golden advice. I am grateful to my best friend, Izabela Klimczak-Ćwierk, for linguistic corrections and feedback. I would also like to thank my colleague, Jakub Kubiczek, for helping me with the Gretl operations.

\section{References}

Altaji, F. S., \& Alokhed, S. K. (2019). The impact of the implementation of international financial reporting standard no. 15 on improving the quality of accounting information. Management Science Letters, 9, 2369-2382. https://doi.org/10.5267/j.msl. 2019.7.018

Altamuro, J., Beatty, A. L., \& Weber, J. P. (2005). The effects of accelerated revenue recognition on earnings management and earnings informativeness: Evidence from SEC Staff Accounting Bulletin No. 101. The Accounting Review, 80(2), 373-401. https://doi.org/10.2308/accr.2005.80.2.373

Baldissera, J. F., Renan, A., Zanchet A., \& Fiirst, C. (2018). Gerenciamento de resultados em companhias do setor de construção civil: influência da adoção do CPC 17 [Earnings management in companies of the construction sector: Influence of CPC 17 adoption]. Revista Universo Contábil, 14(2), 100-117. https://doi.org/10.4270/ ruc. 2018213 
Beatty, A. L., Ke B., \& Petroni K. R. (2002). Earnings management to avoid earnings declines across publicly and privately held banks. The Accounting Review, 77(3), 547-570. https://doi.org/10.2308/accr.2002.77.3.547

Boterenbrood, R. (2014). Income smoothing by Dutch hospitals. Journal of Accounting and Public Policy, 33(5), 510-524. https://doi.org/10.1016/j.jaccpubpol.2014.06.005

Brzeszczyński, J., Gajdka, J., \& Schabek, T. (2011). Earnings management in Polish companies. Comparative Economic Research, 3(14), 137-150. https://doi.org/10.2478 /v10103-011-0023-1

Burgstahler, D., \& Dichev, I. (1997). Earnings management to avoid earnings decreases and losses. Journal of Accounting and Economics, 24(1), 99-126. https://doi.org/ 10.1016/S0165-4101(97)00017-7

Caylor, M. L. (2010). Strategic revenue recognition to achieve earnings benchmarks. Journal of Accounting and Public Policy, 29(1), 82-95. https://doi.org/10.1016/ j.jaccpubpol.2009.10.008

Dechow, P. M., \& Skinner, D. J. (2000). Earnings management: Reconciling the views of accounting academics, practitioners, and regulators. Accounting Horizons, 2(14), 235-250. https://doi.org/10.2308/acch.2000.14.2.235

Giedt, J. Z. (2018). Modelling receivables and deferred revenues to detect earnings management. Abacus, 54(2), 181-209. https://doi.org/10.1111/abac.12119

Glaum, M., Lichtblau, K., \& Lindemann, J. (2004). The extend of earnings management in the U.S. and Germany. Journal of International Accounting Research, Sarasota 3(2), 45-77. https://doi.org/10.2308/jiar.2004.3.2.45

Graham, J. R., Harvey, C. R., \& Rajgopal, S. (2005). The economic implication of corporate financial reporting. Journal of Accounting and Economics, 40(1-3), 3-37. https://doi.org/10.3386/w10550

Hamdi, F. M., \& Zarai, M. A. (2012). Earnings management to avoid earnings decreases and losses: Empirical evidence from Islamic banking industry. Research Journal of Finance and Accounting, 3(3), 88-106.

Healy, P. M., \& Wahlen, J. M. (1999). A review of the earnings management literature and its implications for standard setting. Accounting Horizons, 13(4), 365-383. https://doi.org/10.2308/acch.1999.13.4.365

Holder, A. D., Moore, G., \& Petkevich, A. (2014). Does the new revenue recognition standard improve financial reporting? Internal Accounting, 29(5), 15-25.

Kałdoński, M., \& Jewartowski, T. (2018). Kształtowanie zysków w spółkach notowanych na GPW. Czy charakterystyka inwestorów instytucjonalnych ma znaczenie? [Earnings management in companies listed on Warsaw Stock Exchange. Do institutional investors' characteristics matter?]. Finanse, Rynki Finansowe, Ubezpieczenia, 2(92), 255-267. https://doi.org/10.18276/frfu.2018.92-22

Karwowski, M. (2016). MSSF 15 „Przychody z umów z klientami” a ocena realizacji modelu biznesu [IFRS 15 ,Revenue from contracts with customers” and evaluation of business model implementation]. Studia Ekonomiczne, 285, 161-170. 
Kasznik, R. (2001). The effects of limiting accounting discretion on the informativeness of financial statements: Evidence from software revenue recognition. Stanford GSB Research Paper Series, 1400(R1), 1-45. https://doi.org/10.2139/ssrn.515950

Lizińska, J., \& Czapiewski, L. (2016). Manipulowanie zyskami przez spółki debiutujące na GPW [IPO firms' earnings manipulation on the Warsaw Stock Exchange]. Ruch prawniczy, Ekonomiczny i Socjologiczny, 78(4), 197-212. https://doi.org/10.14746/ rpeis.2016.78.4.15

Malofeeva, T. N. (2018). The impact of IFRS adoption on earnings management in Russia. European Research Studies Journal, 21(2), 147-164. https://doi.org/10.35808/ ersj/991

Marquardt, C. A., \& Wiedman, C. I. (2004). How are earnings managed? An examination of specific accruals. Contemporary Accounting Research, 21(2), 461-491. https://doi.org/10.1506/G4YR-43K8-LGG2-F0XK

Piasecki, M. (2015). Kształtowanie wyników finansowych a wielkość zaciąganego kapitału obcego spółek notowanych na Giełdzie Papierów Wartościowych w Warszawie [Relationship between earnings management and an increase of amount of debt in companies listed on the Warsaw Stock Exchange]. Zeszyty Naukowe Uniwersytetu Szczecińskiego No 854, Finanse, Rynki Finansowe, Ubezpieczenia, 73, 219-228.

Piosik, A. (2021). Revenue recognition in achieving consensus on analysts' forecasts for revenue, operating income and net earnings: The role of implementing IFRS 15. Evidence from Poland. Procedia Computer Science, 192, 1560-1572. https://doi. org/10.1016/j.procs.2021.08.160

Piosik, A., \& Genge, E. (2020). The influence of a company's ownership structure on upward real earnings management. Sustainability, 12(1), 1-24. https://doi.org/ $10.3390 / \mathrm{su} 12010152$

Plummer, E., \& Mest, D. P. (2001). Evidence on the management of earnings components. Journal of Accounting, Auditing \& Finance, 16(4), 301-323. https://doi.org/ 10.1177/0148558X0101600405

Poniatowska, L. (2019). Kierunki zmian w regulacjach prawa bilansowego w obszarze przychodów [Directions of changes in accounting regulations in the area of revenues]. Studia Ekonomiczne, 386, 84-94.

Roychowdhury, S. (2006). Earnings management through real activities manipulation. Journal of Accounting and Economics, 42(3), 335-370. https://doi.org/10.1016/ j.jacceco.2006.01.002

Rutledge, R. W., Karim, K. F., \& Kim, T. (2016). The FASB's and IASB's new revenue recognition standard: What will be the effects on earnings quality, deferred taxes, management compensation, and on the industry-specific reporting? Journal of Corporate Reporting and Finance, 27(6), 43-48. https://doi.org/10.1002/jcaf.22188

Serdarević, N., \& Muratović-Dedić, A. (2021). Revenue recognition and real earnings management in Bosnian construction industry. Journal of Forensic Accounting Profession, 1(1), 21-34. https://doi.org/10.2478/jfap-2021-0002 
Sitarz, N. (2018). Nowy jednolity model ujmowania przychodów według MSSF [The new homogeneous revenue recognition model under IFRS]. Prace Naukowe Uniwersytetu Ekonomicznego we Wrocławiu 503. Research Papers of Wrocław University of Economics, 503, 411-421. https://doi.org/10.15611/pn.2018.503.36

Stallworth, H. L., \& Braun, R. L. (2007). Computone corporation: An instructional case in earnings management and revenue recognition. Issues in Accounting Education, 22(2), 319-332. https://doi.org/10.2308/iace.2007.22.2.319

Stallworth, H. L., \& Digregorio, D. (2004). Improper revenue recognition: To help clients avoid SEC violations, internal auditors need to understand the revenue management practices that can lead to material misstatements. Internal Auditor, 61(3), 53-57.

Staszel, A. (2019). Obszary swobody $w$ rachunkowości [The latitude areas in accounting]. Warszawa: Difin.

Strojek-Filus, M. (2016). Zarządzanie wynikiem finansowym i sferą regulacyjną sprawozdań finansowych $\mathrm{z}$ perspektywy finansów behawioralnych [The impact of aspects of behavioral finance at earnings management practices and the financial reports law]. Studia Ekonomiczne, 274, 26-35.

Stubben, S. R. (2010). Discretionary revenues as measure of earnings management. The Accounting Review, 85(2), 695-717. https://doi.org/10.2308/accr.2010.85.2.695

Toumeh, A. A., \& Yahya, S. (2019). A review of earnings management techniques: An IFRS perspective. Global Business and Management Research: An International Journal, 11( 3), 1-13.

Tutino, M., Regoliosi, C., Mattei, G., Paoloni, N., \& Pompili M. (2019). Does the IFRS 15 impact earnings management? Initial evidence from Italian listed companies. African Journal of Business Management, 13(7), 226-238. https://doi.org/10.5897/ AJBM2018.8735

Walińska, E., \& Jurewicz, A. (2015). Koncepcje ujmowania przychodów w systemie rachunkowości - stan obecny i proponowane zmiany [Concepts of revenue recognition in accounting system - current and proposed changes]. Zeszyty Naukowe Uniwersytetu Szczecińskiego. Finanse, Rynki Finansowe, Ubezpieczenia, 77(873), 211-223. https://doi.org/10.18276/frfu.2015.77-22

Wójtowicz, P. (2010). Wiarygodność sprawozdań finansowych wobec aktywnego ksztattowania wyniku finansowego [The reliability of financial statements in the face of active earnings management practices]. Kraków: Wydawnictwo Uniwersytetu Ekonomicznego.

Zhang, Y. (2005). Revenue recognition timing and attributes of reported revenue: The case of software industry's adoption of SOP 91-1. Journal of Accounting and Economics, 39(3), 535-561. https://doi.org/10.1016/j.jacceco.2005.04.003 